\title{
Response of wether lambs to implantation with trenbolone acetate combined with oestradiol-17 $\beta$ at two levels of dietary protein
}

\author{
J.F.S. COELHO, H. GALBRAITH and J.H. TOPPS \\ Division of Chemistry and Biochemistry, School of Agriculture, \\ 581 King Street, Aberdeen, AB9 1UD, Scotland
}

\begin{abstract}
Summary
Ten Border Leicester $\times$ Blackface castrated male lambs from a group of 20 of $33 \mathrm{~kg}$ mean initial live weight were offered a diet (LP) which provided (per kg dry matter (DM)) $12.2 \mathrm{MJ}$ metabolisable energy (ME) and $0.120 \mathrm{~kg}$ crude protein (CP). The remaining ten lambs were offered an approximately iso-energetic diet which provided $0.148 \mathrm{~kg} \mathrm{CP} / \mathrm{kg} \mathrm{DM}(\mathrm{HP})$. The feeding level for both groups was approximately 2.5 times the estimated maintenance requirement. Five lambs in each of the dietary groups were subcutaneously implanted with a combination of $60 \mathrm{mg}$ trenbolone acetate (TBA) and $12 \mathrm{mg}$ oestradiol-17 $\left(\mathrm{OE}_{2}\right), 54$ days before slaughter ; the remainder were untreated.

The anabolic treatment resulted in significant improvements in live weight gain, and food conversion efficiency and carcass weight. The implanted lambs had heavier and longer carcasses which contained more protein and water and had greater mean values for depth of thorax and width of rib than controls. Significant reductions due to implantation were recorded for concentrations of urea and free fatty acids in blood plasma and for proportions of wool fleece and kidney plus channel fat in the empty body weight (EBW). The anabolic treatment also resulted in significant increases in the weight $(\mathrm{g} / \mathrm{kg} \mathrm{EBW})$ of liver, and increases in the activity of L-alanine aminotransferase, in the content of RNA, and reductions in the content of DNA in whole liver. Significant increases in the ratio of hepatic RNA to DNA were recorded. The largest differences due to hormonal treatment tended to occur on the lower protein diet (LP).

Certain significant effects due to protein level were recorded. These included significantly greater values for plasma urea, the weight $(\mathrm{g} / \mathrm{kg} E B W$ ) of carcass fat, kidney plus channel fat, and the activities of hepatic L-alanine aminotransferase and L-aspartate aminotransferase in group HP compared with group LP.
\end{abstract}

Key words : wether lambs, implantation, trenbolone acetate, oestradiol-173, dietary protein.

\section{Introduction}

A combination of trenbolone acetate (TBA) and oestradiol-17 $\beta\left(\mathrm{OE}_{2}\right)$ has been reported to improve liveweight gain and food conversion efficiency in cattle and sheep (Galbraith \& Topps, 1981 ; Coelho, Galbraith \& Topps, 1981 ; Sinnett-Smith, Dumelow \& Buttery, 1983). These improvements in growth performance have been 
associated with an increased accretion of protein tissue within the animal. The present experiment was designed to study the effect of a similar hormonal preparation on castrated male lambs, at two levels of dietary protein. Certain organs and body parts were weighed and some metabolic characteristics were measured, with a view to providing information on some aspects of the mechanism of action of the hormonal treatment.

\section{Materials and Methods}

Twenty Border Leicester $\times$ Blackface castrated male lambs, weighing initially approximately $33 \mathrm{~kg}$ were used. They were individually penned and allocated in groups of 10 to receive, twice daily, pelleted feed containing ( $\mathrm{kg}$ per $\mathrm{kg}$ dry matter (DM)) either bruised barley 0.850 and hay 0.150 (low protein (LP) diet), or barley 0.780 , hay 0.150 , fish meal 0.070 (high protein (HP) diet). These diets provided (per $\mathrm{kg} \mathrm{DM}$ ) approximately $12.2 \mathrm{MJ}$ metabolizable energy (ME) and $0.120 \mathrm{~kg}$ crude protein (CP) or $0.148 \mathrm{~kg} \mathrm{CP}$, respectively. Estimated concentrations of rumen degradable (RDP) (ie. protein estimated to be degraded in the rumen) and undegradable protein (UDP) (ie. protein considered not to be degraded in the rumen) (Scottish Agricultural ColLeges, 1978 ; Agricultural Research Council, 1980) were (kg per kg DM) 0.092 and 0.028 for diet LP, and 0.096 and 0.052 for diet HP, respectively.

A suitable mineral and vitamin mixture was added to both diets. The level of feeding was designed to provide about 2.5 times their mean estimated maintenance requirement for ME (Scottish Agricultural Colleges, 1978). Following a 4-week period of adaptation to experimental conditions, five lambs in each dietary group were allocated to be untreated controls or to be implanted at the base of the ear with three pellets of «Torelor» (Roussel-UCLAF, Paris) containing $60 \mathrm{mg}$ TBA $+12 \mathrm{mg} \mathrm{OE} 2$, at the start of a 54-day experiment. Allocation to treatment groups was by randomised block design based on live weight. Lambs were weighed and their blood sampled by jugular venepuncture, at intervals of three weeks. Blood samples were prepared and analysed as described previously (GALBraith, 1982).

At the end of the experiment all animals were slaughtered and their carcasses, as well as some organs and body parts, were weighed and analysed essentially as described earlier (Coelho, Galbraith \& Topps, 1981). Measurements of length of leg, maximum rib width, (measured with calipers on the exterior surface of the carcass) « fullness of thighs 》 and width of gigots were made on the whole carcass, which was then split along the vertebral column and the following measurements made on the left side : carcass length, maximum depth of thorax behind shoulder (PALsSON, 1939).

The activity of both L-alanine and L-aspartate aminotransferase was estimated in a liver extract in potassium phosphate, pH 7.5 (Goldstone \& AdAMs, 1962) by means of a test combination (GOT/GPT kit, Boehringer Mannheim). Protein in the liver extract was estimated by the method of Lowny et al. (1951). Enzyme activity was expressed as Units per weight of whole liver and in Units per $\mathrm{mg}$ soluble protein in liver.

A modification of the method of Schmidt-Thannhauser was used (MUNRo \& FLEcK, 1966) for the estimation of ribonucleic acid in liver, while deoxyribonucleic acid was determined in the same tissues by the method of Burton (1956). 
Statistical significance for the main treatment effects and their interaction was tested by analysis of variance $F$ test, involving individual data from all experimental groups. Comparisons between means for treated and control lambs in each dietary group were made by t-test. The interaction term is not routinely included in the tables of results, but where significance occurred, it is given by a foot-note. One lamb was removed from the experiment in treatment group LP and «missing values » for this animal were calculated.

\section{Results}

\section{A. Animal performance}

There was an increase in mean total live weight gain associated with anabolic implantation, especially so $(P<0.01)$ in lambs fed the LP diet $(6.5$ and $12.6 \mathrm{~kg}$ for control and treated lambs, respectively) (tabl. 1). Effects on total live weight gain due to dietary protein level were not significant. Mean values for total dry matter intake were similar in all groups (on average $67 \mathrm{~kg}$ ). The efficiency of conversion of feed dry matter into LWG (DMI/LWG) was significantly improved due to implantation, (68 p. $100, \mathrm{P}<0.01)$, the largest difference being recorded between control and treated lambs on diet LP (113 p. 100).

Mean cold carcass weights of implanted animals were also greater than those for controls, the increase being significant for animals on diet LP $(14$ p. $100, P<0.01)$.

\section{B. Blood parameters}

As shown in tabl. 2, mean values for plasma urea were significantly reduced on diet LP compared with HP and, on average, in hormonally treated lambs compared with controls. However, the anabolic effect may be attributed exclusively to that occurring on diet LP $(30$ p. 100 reduction, $P<0.01)$ with a trend towards an increased concentration in treated lambs on diet HP compared with controls. The diet $\times$ implant interaction for urea tended towards significance $(p<0.1)$. Mean values for plasma glucose were significantly reduced on diet LP compared with diet HP, but apparently increased in implanted lambs on diet LP and decreased in implanted lambs on diet HP. A significant reduction in the concentration of free fatty acids was recorded due to implantation. The larger difference was recorded on diet HP $(32$ p. 100, P < 0.05).

\section{Carcass measurements}

Implanted lambs had longer carcasses than controls (3.8 p. 100 increase), and greater mean values for maximum depth of thorax behind the shoulders and maximum rib width $(2.7$ p. 100 and 8.2 p. 100 , respectively). These effects were significant $(\mathrm{P}<0.05)$, and again more marked within the group fed the LP diet (tabl. 2). Measurements were also made for width of gigots, length of leg and « fullness of thighs " but no significant effects, of either the anabolic treatment or dietary protein level, were recorded. 


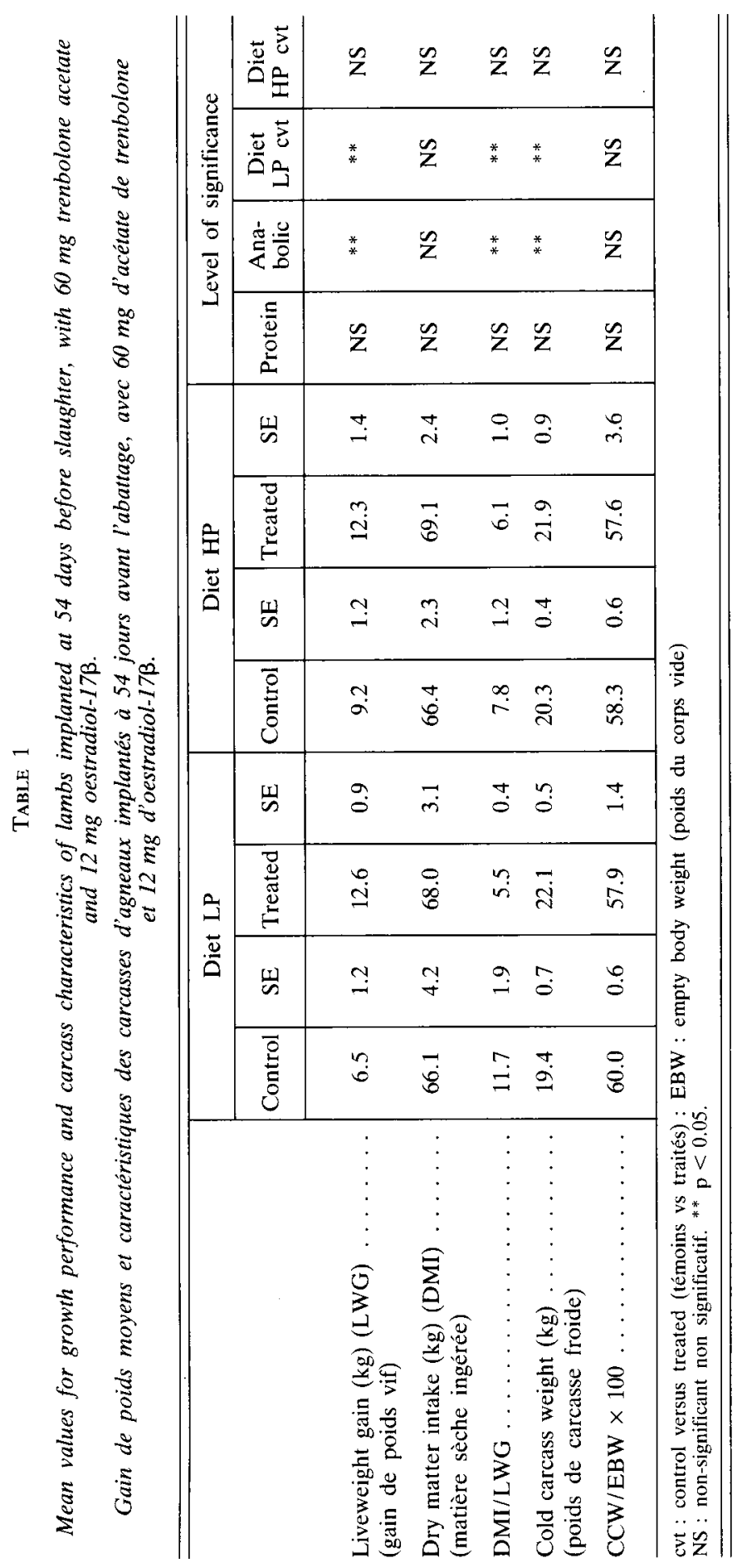




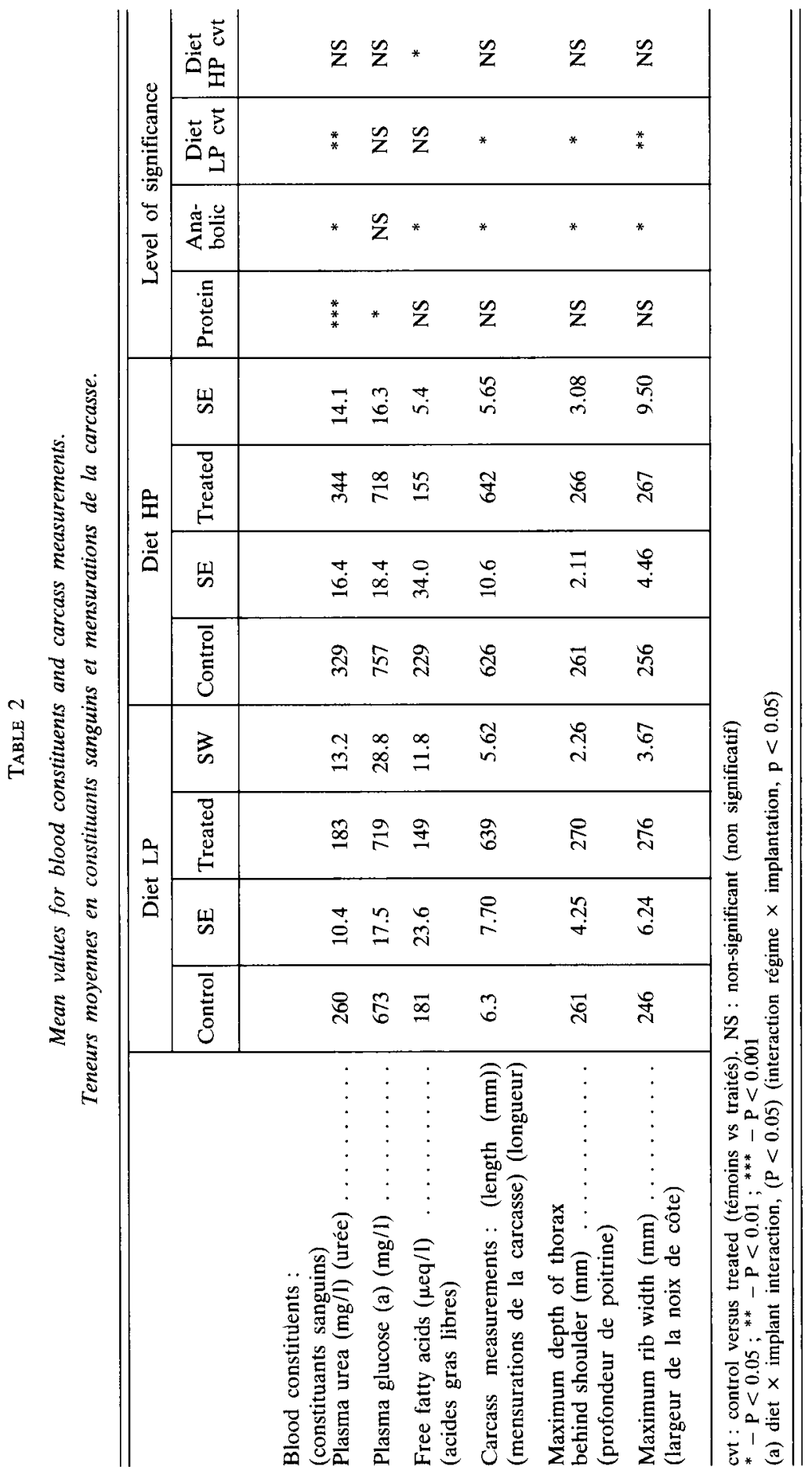




\section{Composition of carcass}

Implanted lambs had significantly greater mean values for crude protein $(\mathrm{P}<0.01)$ and moisture $(p<0.05)$ than controls (tabl. 3). There were no significant differences, due to implantation, in the total amounts of fat, ash, calcium and phosphorus. The only significant effect of diet was a significantly greater fat content in lambs given diet $\mathrm{HP}$ compared with those offered diet LP.

\section{E. Organs and body parts}

Mean weights for liver as a fraction of empty body weight were significantly increased due to implantation $(P<0.05)$, particularly so in lambs on diet LP $(21.5 \mathrm{p}$. 100) (tabl. 4). An increase in the weight of kidneys was also apparent in treated lambs given diet LP, but not in those offered diet HP. Variable and non-significant responses were obtained for mesenteric fat and fat-free digestive tract. A significant effect of dietary protein was observed for kidney and channel fat in that animals given diet LP had significantly lower mean values than those on diet HP. Mean values for wool fleece and teat length were significantly decreased and increased, respectively, by the hormonal treatment.

\section{F. Aminotransferase activity in liver and muscle}

As shown in tabl. 5, the activity of both L-alanine aminotransferase (A1 AT) and L-aspartate aminotransferase (As AT) in the whole liver tended to be higher in implanted animals than in controls, the difference being significant only for A1 AT within the LP diet group $(\mathrm{P}<0.01)$. This may be attributed to the presence of larger livers in implanted lambs, since enzyme specific activities $(\mathrm{U} / \mathrm{mg}$ soluble protein) for A1 AT were similar in all treatments. There was also a significant increase in the activity of both enzymes in whole liver, due to raising feed protein. However, only the specific activity of As AT was significantly increased in lambs given diet HP compared with those fed on diet LP.

\section{G. Levels of nucleic acids in liver}

There was a significant $(P<0.01)$ increase, due to the anabolic treatment, in the total amount, but not the concentration, of RNA in liver. The difference between control and treated lambs was significant for the LP diet group $(\mathbf{P}<0.001)$ (tabl. 5). The values for the concentrations of DNA $(\mathrm{mg} / \mathrm{g}$ tissue $)$ were significantly $(\mathbf{P}<0.05)$ reduced due to implantation effect, mainly within the LP diet group, while those for total DNA were higher, but not significantly so, in treated lambs, in group LP, compared with controls. Implantation also increased significantly $(P<0.05)$ the ratio of RNA to DNA, again mainly within the LP diet group. On the other hand, the ratios of total DNA and total RNA to total soluble protein in the liver did not show any significant differences between treatments. 


\begin{tabular}{|c|c|c|c|c|c|c|c|c|c|}
\hline & & 岂 & $\stackrel{*}{*}$ & $\tilde{z}$ & $\tilde{z}$ & $\tilde{z}$ & $\tilde{z}$ & $\frac{n}{z}$ & \\
\hline & 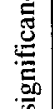 & בص & $*$ & $\tilde{z}$ & * & $\tilde{z}$ & $\tilde{z}$ & $\tilde{Z}$ & \\
\hline & $\begin{array}{l}4 \\
\overline{0} \\
\overline{2}\end{array}$ & $\stackrel{\frac{1}{2}}{\frac{0}{2}}$ & $*$ & $\tilde{z}$ & * & $\tilde{z}$ & $\tilde{z}$ & $\tilde{z}$ & \\
\hline & & $\begin{array}{l}\frac{1}{0} \\
\frac{0}{0} \\
0\end{array}$ & $\tilde{z}$ & $\stackrel{*}{*}$ & $\tilde{z}$ & $\tilde{z}$ & $\tilde{Z}$ & $\tilde{z}$ & \\
\hline & & 땡 & $\dddot{O}$ & $\stackrel{ }{0}$ & $\stackrel{0}{0}$ & $\stackrel{P}{\forall}$ & $\stackrel{\infty}{\infty}$ & ్ㅗ & \\
\hline 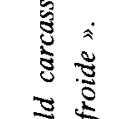 & 界 & 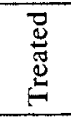 & $\stackrel{\sim}{\forall}$ & $\stackrel{g}{b}$ & $\stackrel{\varrho}{\varrho}$ & $\underset{8}{8}$ & E & $\underset{-}{\stackrel{\Xi}{\sigma}}$ & \\
\hline $\begin{array}{l}8 \\
\Xi \\
\Xi\end{array}$ & $\stackrel{0}{\theta}$ & 岕 & $\stackrel{?}{0}$ & $\dot{0}$ & $\overrightarrow{0}$ & $\infty$ & ले & 9 & \\
\hline 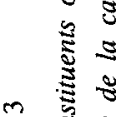 & & 苞 & $\vec{m}$ & $\hat{b}$ & $\stackrel{\infty}{\infty}$ & 8 & $\stackrel{v}{p}$ & $\Xi$ & \\
\hline 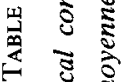 & & 岁 & $\overrightarrow{0}$ & $\stackrel{\nabla}{0}$ & 3 & 8 & $\vec{\imath}$ & $=$ & \\
\hline 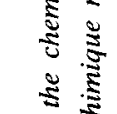 & 3 & $\begin{array}{l}\vec{D} \\
\stackrel{\Xi}{\Xi} \\
E\end{array}$ & $\overrightarrow{+}$ & $\ddot{0}$ & $\stackrel{+}{\stackrel{\theta}{\varrho}}$ & 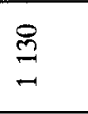 & $\overrightarrow{\mathrm{v}}$ & $\tilde{2}$ & \\
\hline$\stackrel{5}{3}$ & $\ddot{\Delta}$ & 땡 & $\overrightarrow{0}$ & 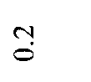 & $\stackrel{\circ}{\circ}$ & 8 & $m$ & $\simeq$ & \\
\hline 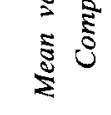 & & $\bar{\delta}$ & $\stackrel{n}{n}$ & $\begin{array}{l}\infty \\
\dot{n}\end{array}$ & $\stackrel{a}{\infty}$ & 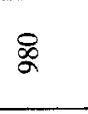 & $\stackrel{m}{m}$ & $\stackrel{9}{I}$ & \\
\hline & & & 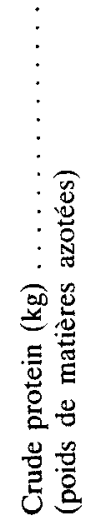 & 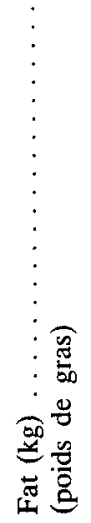 & 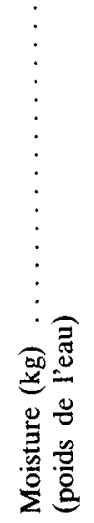 & 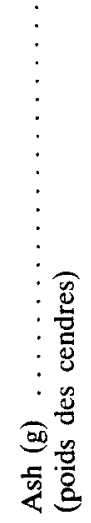 & 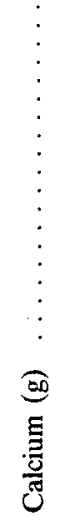 & 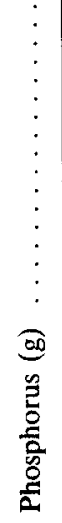 & 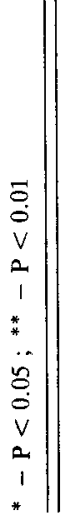 \\
\hline
\end{tabular}




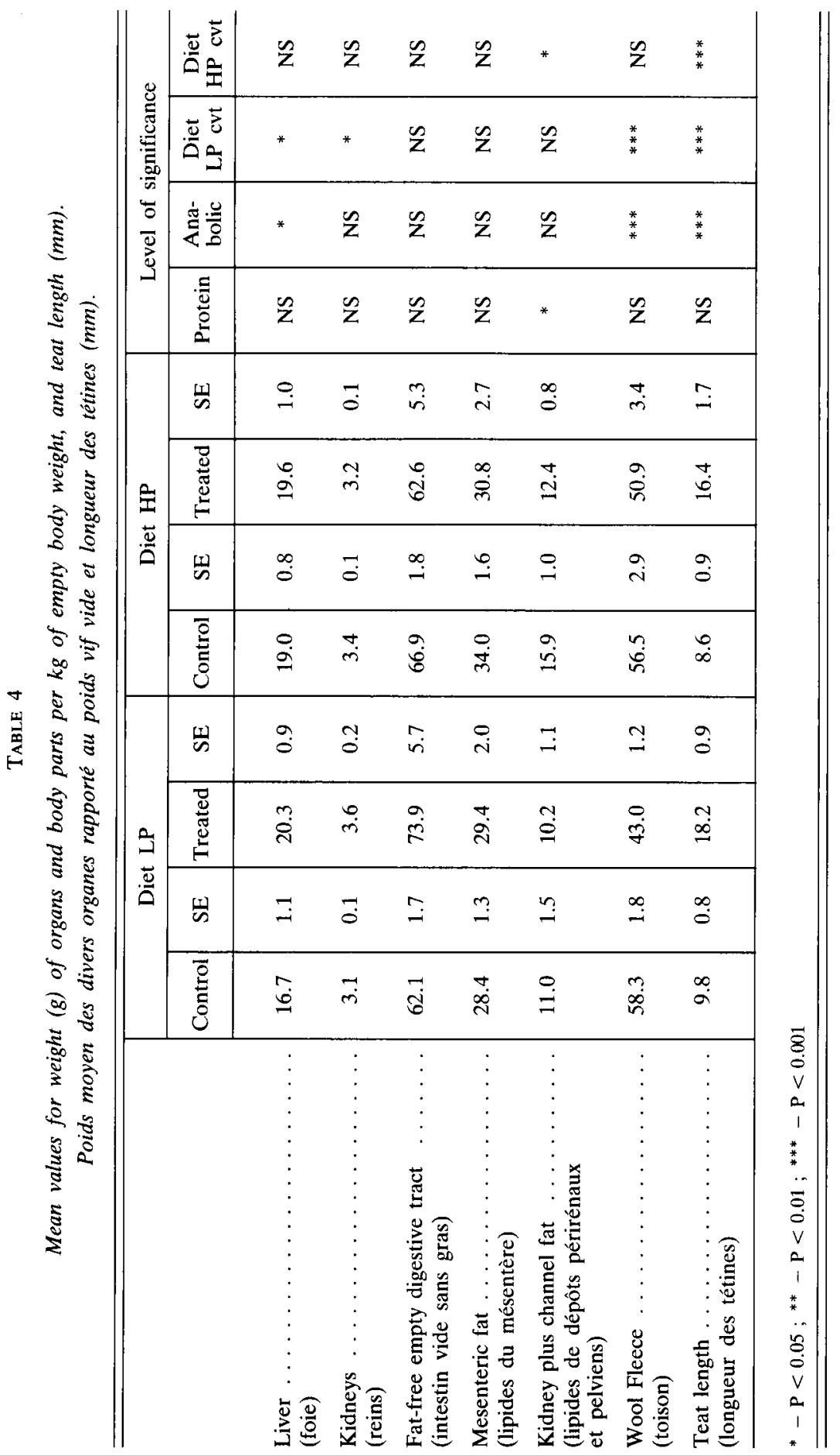


离突

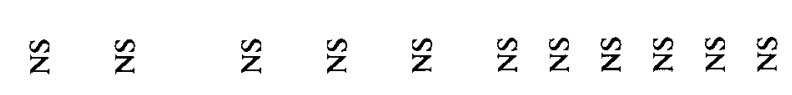
氖 离芳

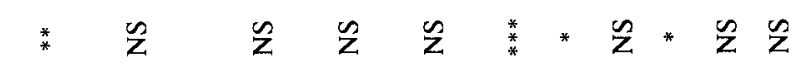

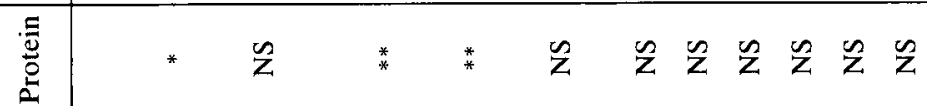

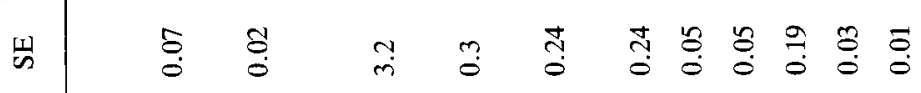

\begin{tabular}{|c|c|c|c|c|c|c|c|c|c|c|c|}
\hline 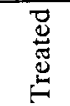 & 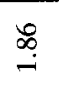 & ב. & $\stackrel{m}{\stackrel{n}{n}}$ & $\stackrel{0}{\dot{f}}$ & $\begin{array}{l}\vec{b} \\
\text { in }\end{array}$ & $\vec{\nabla}$ & $\sqrt[n]{3}$ & $\stackrel{\infty}{\rightleftarrows}$ & in & స్తి & $\vec{\Xi}$ \\
\hline
\end{tabular}

$\stackrel{\vec{\omega}}{\stackrel{D}{\omega}}$

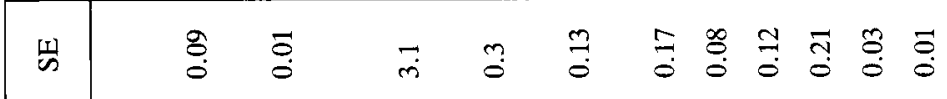

\begin{tabular}{|c|c|c|c|c|c|c|c|c|c|c|c|}
\hline $\begin{array}{l}\bar{D} \\
\text { 苛 }\end{array}$ & $\stackrel{8}{8}$ & $\stackrel{\infty}{\stackrel{0}{0}}$ & $\begin{array}{l}0 \\
\dot{+}\end{array}$ & $\begin{array}{l}\infty \\
\dot{\forall}\end{array}$ & $\stackrel{0}{\dot{\varphi}}$ & $\underset{\sim}{\sigma}$ & $\stackrel{N}{g}$ & $\stackrel{?}{=}$ & $\bar{r}$ & $\stackrel{\infty}{\varrho}$ & $\stackrel{9}{9}$ \\
\hline
\end{tabular}

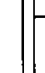

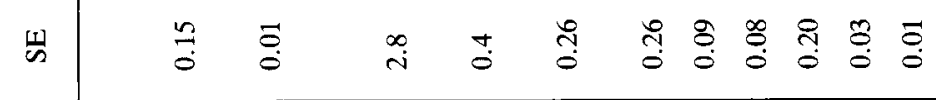

$\sum_{\Sigma}^{2}$

¿

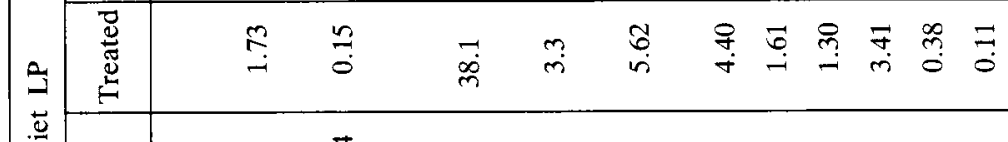

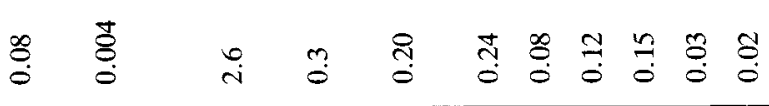

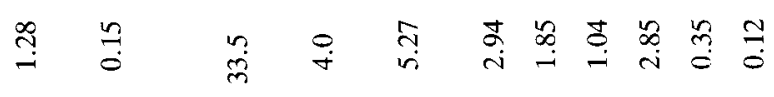

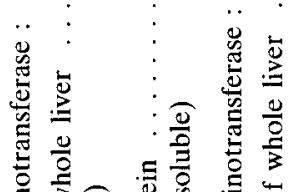

$\frac{\pi}{2}$

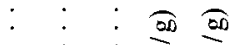




\section{Discussion and Conclusion}

In the present experiment there was an increase in the LWG of wether lambs which was associated with implantation of $60 \mathrm{mg}$ TBA $+12 \mathrm{mg} \mathrm{OE}_{2}$. This effect was particularly marked in lambs given diet LP in which treated lambs gained approximately 94 p. 100 more than controls. The apparently larger response to hormonal treatment on diet LP may be partially attributed to the poor growth performance of control lambs $(120 \mathrm{~g} / \mathrm{d}$ on average). This value is considerably less than the $\mathrm{LWG}$ of $230 \mathrm{~g} / \mathrm{day}$ predicted from their ME intake (Agricultural Research Council, 1980), and 50 g/day on average less than the growth rate of control lambs on diet HP consuming a similar amount of dietary energy. The differences in growth performance may therefore be mainly explained by the difference (estimated at $4 \mathrm{~g}$ RDP and $29 \mathrm{~g}$ UDP) between diets LP and HP, in the average daily supply of dietary protein. Mean values for the consumption of feed dry matter on the two diets were similar suggesting that protein level did not affect intake.

However, the LWG of treated lambs on both diets was similar. This result suggests that the protein level in diet LP may have been adequate to maximise the response to the hormonal treatment, at least to that of lambs on diet HP. If so, the effect of the hormonal compounds in animals on diet LP included a large increase in the efficiency with which they utilised dietary protein. Similarly, mean values for food conversion efficiency were superior and those for carcass weight were greater in implanted animals, compared with controls, the difference being larger for lambs given diet LP. These results confirm the positive effects on growth performance and carcass accretion of wether lambs given the combination of TBA $+\mathrm{OE}_{2}$ (Coelho, Galbraith \& Topps, 1981 ; Sulieman, Galbraith \& Topps, 1986). The results also suggest that the magnitude of growth response may well depend on the level of protein in the diet, possibly being larger at approximately the recommended dietary protein levels, or slightly below. This confirms the findings of Galbraith \& Coelho (1978), using steers implanted with trenbolone acetate plus hexoestrol, and of Powell (1973), using hexoestrol implanted calves, who reported a reduction in growth response to hormonal compounds, obtained by increasing the levels of dietary protein above the estimated requirement.

The depression of plasma urea levels in the implanted animals on the LP diet (but not in the HP diet group) is similar to that observed previously in wether lambs (Coelho, Galbraith \& Topps, 1981 ; Yasin \& Galbraith, 1981). The change in this metabolite on diet LP was accompanied by a performance effect apparently greater than that obtained on the HP diet, which supports the suggestion made earlier of a more efficient protein utilisation in the implanted lambs on the LP diet. This may arise from a greater reduction of amino acid catabolism and urea formation, such as that suggested to occur by Sinnetr-Smith, Dumelow \& Buttery (1983), in sheep given $140 \mathrm{mg}$ TBA $+20 \mathrm{mg} \mathrm{OE}$, and by LoBley et al. (1985), in cattle given a similar dose of the two steroids. The elevated concentration of plasma glucose on the high protein diet could be partially explained by an increased utilisation of additional amino acids for gluconeogenesis. However, further work is required to explain the different effects of implantation on the two protein diets. The significant reduction in mean values for plasma free fatty acids may be explained on diet LP but not on diet HP (where mean glucose concentrations decreased in treated animals) by the additional energy for 
metabolic processes derived from glucose, which, according to higher plasma concentrations appeared to be more available.

Hormonal implantation resulted in carcasses of treated lambs which were longer, as well as wider and deeper in the forequarter as shown by effects on rib width and depth of thorax respectively at the same time as being heavier than controls. The carcasses of implanted lambs also contained greater quantities of crude protein and water than those of controls. These results broadly confirm those observed and discussed by CoElHo, GalBRAITH \& TOPPS (1981). However, a significant effect of protein was obtained for carcass fat deposition. It may be speculated that additional amino acids derived from diet HP were utilised for the accretion of fat. An alternative explanation may be that metabolic energy demands were partially met by oxidation of additional dietary amino acids, thereby sparing fat catabolism.

The anabolic treatment resulted in a significant increase in liver weight, as a fraction of empty body weight, with the largest difference between control and treated lambs occurring on diet LP. The values for kidney weight were also greater for implanted lambs than controls, but only on diet LP. The significance of relative increases in the weights of these organs following TBA $+\mathrm{OE}_{2}$ treatment has been discussed previously (Coelho, Galbraith \& TopPs, 1981). The effects due to differences in dietary protein level were not significant. The hormonal implantations resulted in variable reductions in the content of kidney + channel fat and wool fleece $(\mathrm{P}<0.001)$ and increases in teat length $(\mathrm{P}<0.001)$ similar to those observed and discussed previously (Coelho, Galbraith \& TopPs, 1981).

The content of kidney + channel fat was significantly influenced by dietary protein level similar to that observed for carcass fat. This effect provides further evidence of a change in the metabolic energy economy of the animal, attributable to dietary protein.

The significant increase in teat length in implanted lambs may be attributed to the oestrogenic nature of the implant, as discussed by Coelho, Galbraith \& Topps (1981).

The activities of liver aminotransferase enzymes were measured to investigate the effects of direct hormonal implantation and increased amino acid supply on aspects of hepatic protein metabolism.

Although the specific activity in liver of A1 AT was similar within both dietary groups, enzyme activity in the whole liver was significantly higher in implanted lambs compared with controls, because implanted animals on the LP diet had larger livers. YASIN \& GALBRAITH (1981) also found an increase in liver aminotransferase activity associated with augmented protein deposition in the carcass of lambs implanted with a combination of TBA and $\mathrm{OE}_{2}$ or TBA and zeranol.

The major effect on the specific activity of L-aspartate aminotransferase, in the present experiment, was a significant increase in lambs given the high protein diet, compared with those on the low protein diet, which was also observed in A1 AT in whole liver. This may be due to an increased requirement for metabolism of additional amino acids supplied in diet HP.

There were no significant effects due to implantation or dietary protein level on the concentration of RNA in liver. However, total quantities of RNA were increased as a consequence of larger livers in the treated groups, particularly so in group LP. In contrast, the concentrations of hepatic DNA were significantly reduced by implantation, although the total quantities were not significantly altered by diet or hormonal treat- 
ment. Sinnetr-Smith, Dumelow \& Buttery (1983), also reported decreased DNA concentrations, with RNA concentrations also decreased, in muscle of female lambs treated with TBA. Comparisons of the ratio of total RNA to DNA, in the present experiment, indicated a significant increase due to implantation. As the amount of DNA is related to nuclear number (YouNG, 1976) and since the greater part of RNA is ribosomal (MILLwARD et al., 1976) this increased ratio may indicate the formation of larger hepatic cells due to the anabolic action of $\mathrm{TBA}+\mathrm{OE}_{2}$. However, there were no significant differences due either to implantation or level of dietary protein on the ratios of total hepatic DNA or total RNA to soluble protein.

In conclusion, the data presented in this study suggest that the response of wether lambs implanted with $\mathrm{TBA}+\mathrm{OE}_{2}$ relative to untreated controls, depends on the concentration of protein in the diet. The largest responses on growth, carcass and metabolic characteristics tended to occur on the diet containing the lowest level of dietary protein.

It is considered that future studies could profitably examine the response of hormonal implantation of sheep given diets containing protein levels in excess of those used in the present investigation. These studies would provide more information on hormonal and dietary factors governing growth in sheep.

\section{Received on January 1985. \\ Accepted on October 1986.}

\section{Acknowlegements}

The authors wish to thank Messrs J. Struthers, N. Lokke and T.W. Begg for the care of experimental animals, and $D^{r}$ A.L. Gelman, Mr. G. Pratt, Mr. D.G. Kerth and supporting staff for analytical assistance. The use of carcass preparation facilities at the Rowett Research Institute and the assistance of Mr. K. PENNIE are also gratefully acknowledged.

\section{Résumé}

Influence d'une implantation d'acétate de trenbolone associé à de l'oestradiol-17 $\beta$ sur les performances d'agneaux recevant deux niveaux d'apports protéiques dans la ration

Vingt agneaux castrés Border Leicester $\times$ Blackface, d'un poids initial de $33 \mathrm{~kg}$ ont été répartis en 2 lots de 10 animaux. Les uns ont été nourris avec un aliment (LP), contenant $12.2 \mathrm{MJ}$ d'énergie métabolisable et $120 \mathrm{~g}$ de protéine par $\mathrm{kg}$ de matière sèche (MS) ; les autres ont reçu un aliment sensiblement isoénergétique, mais plus riche en protéines (148 g par $\mathrm{kg}$ MS (HP)). Le niveau alimentaire a été presque de 2,5 fois le besoin d'entretien estimé. Dans chaque lot, 54 jours avant l'abattage, 5 agneaux ont reçu un traitement anabolisant par implantation dans l'oreille de $60 \mathrm{mg}$ d'acétate de trenbolone (TBA) et de $12 \mathrm{mg}$ d'oestradiol-17 $\beta\left(\mathrm{OE}_{2}\right)$.

Le gain de poids vif, l'efficacité alimentaire et le poids de carcasse ont été significativement augmentés par ce traitement. Il en est de même de la longueur des carcasses, de leur teneur en protéine et en eau, de la profondeur de poitrine et de la largeur maximale de la noix de côte. En revanche, les concentrations plasmatiques en urée et acides gras libres ainsi que le poids de la toison et celui des dépôt adipeux périrénaux et pelviens ( $\mathrm{g}$ par $\mathrm{kg}$ de poids vif vide (EBW)), ont été plus faibles chez les agneaux traités que chez les témoins. Le traitement anabolisant a provoqué aussi une augmentation significative du poids du foie ( $\mathrm{g}$ par $\mathrm{kg} \mathrm{EBW})$, de l'activité de la L-alanine aminotransférase et de la quantité de RNA hépatique, ainsi qu'une diminution de la 
quantité de DNA. Il en résulte une augmentation significative du rapport RNA/DNA dans le foie. C'est avec l'aliment LP que les différences les plus importantes ont été observées. L'accroissement du taux protéique de la ration s'est traduit, par une augmentation significative de la teneur en urée plasmatique, du poids de lipides dans la carcasse $(\mathrm{g} / \mathrm{kg} \mathrm{EBW})$, des dépôts périrénaux et pelviens et de l'activité de la L-alanine aminotransferase et la L-aspartate aminotransférase hépatique.

Mots clés : Agneaux, implantation, acétate de trenbolone, oestradiol-17ß, protéine alimentaire.

\section{References}

Agricultural Research Council, 1980. Requirements for energy. In : The Nutrient Requirements of Ruminant Livestock, 73-119. Commonwealth Agricultural Bureaux, Slough, Great Britain.

Burton K., 1956. A study of conditions and mechanism of the diphenylamine reaction for the colorimetric estimation of deoxyribonucleic acid. Biochem. J., 62, 315-322.

Coelho J.F.S., Galbraith H., TopPS J.H., 1981. The effect of a combination of trenbolone acetate and oestradiol-17 $\beta$ on growth performance and blood, carcass and body characteristics of wether lambs. Anim. Prod., 32, 261-266.

Galbraith H., 1982. Growth, hormonal and metabolic response of post-pubertal entire male cattle to trenbolone acetate and hexoestrol. Anim. Prod., 35, 269-276.

Galbraith H., Coelho J.F.S., 1978. Effect of dietary protein intake and implantation with trenbolone acetate and hexoestrol on the growth performance and blood metabolites and hormones of British Friesian male cattle. Anim. Prod., 26, 360.

Galbraith H., TopPS J.H., 1981. Effect of hormones on the growth and body composition of animals. Nutr. Abst. \& Reviews Ser. B, 51, 521-540.

Goldstone A., Adams E., 1962. Metabolism of $\alpha$-hydroxyglutaric acid. J. Biol. Chem., 237, 34763485 .

Lobley G.E., Connel A., Mollison G.S., Brewer A., Harris I.C., Buchan V., Galbraith H., 1985. The effects of a combined implant of trenbolone acetate and oestradiol-17 $\beta$ on protein and energy metabolism in growing beef steers. Br. J. Nutr., 54, 681-694

Lowry O.H., Rosebrough N.J., Farr A.L., Randall R.J., 1951. Protein measurement with the Folin Phenol reagent. J. Biol. Chem., 193, 265-275.

Millward D.J., Garlick P.J., James W.P.T., Sender P.M., Waterlow J.C., 1976. Protein turnover. In (D.J.A. Cole et al. (Ed.)). Protein Metabolism and Nutrition, European Association for Animal Production. Publ. $n^{\prime} 16,49-69$.

Munro H.N., Fleck A., 1966. The determination of nucleic acids. In Methods of Biochemical Analysis (Ed. D. Glick). Vol. 14. Interscience Publ., London, 113-176.

Palsson H., 1939. Meat qualities in the sheep with special reference to Scottish breeds and crosses. J. Agric. Sci., Camb., 29, 544-626.

Powell T.L., 1973. Concentrate composition and hormone implantation for intensively fed weaned suckled calves. Exptl. Husb., 24, 24.

Scottish Agricultural Colleges, 1978. Nutrient Allowances for Cattle and Sheep. Publication $\mathrm{n}^{\circ} 29$.

Sinnett-Smith P.A., Dumelow W., Buttery P.J., 1983. Effects of trenbolone acetate and zeranol on protein metabolism in male castrate and female lambs. Br. J. Nutr., 50, 225-234.

Sulieman A.H., Galbraith H., Topps J.H., 1986. Growth performance and body composition of early weaned wether lambs treated with trenbolone acetate combined with oestradiol-17 $\beta$. Anim. Prod., 43, 109-114.

Yasin A.R.M., Galbraith H., 1981. A note on the response of wether lambs to treatment with trenbolone acetate combined with oestradiol-17 $\beta$ or zeranol. Anim. Prod., 32, 337-340.

Young, 1976. An overview of protein synthesis, degradation and regulation of protein content in skeletal muscle. In (F.C. Lu; J. Rendel (Ed.)), Anabolic Agents in Animal Production, E.Q.S. Supplement Volume V, 20-42, Georg Thieme, Stuttgart. 